\title{
How safe is the cheeses sold in Beni-suef city
}

\author{
Saadia H. El.Shinawy, Mona H. A. Tolba. \\ Department of Food hygiene, Faculty of Veterinary Medicine, Beni-Suef, University, Beni-Suef, Egypt.
}

\begin{abstract}
The incidence of $E$. coli O157, Salmonella typhimurium, Listeria monocytogenes, and Yersinia enterocolitica were studied in some locally produced cheeses. Thirty samples of each kind of the cheese were tested for the presence of some pathogens, which are frequently associated with food born disease. E. coli O157: IMS; Listeria monocytogenes were enumerated on modified Oxford agar; Salmonella was enumerated using standard procedures from Dynal manual using anti-Salmonella antibodies. $Y$. enterocolitica was enumerated on Yersinia selective agar base. Romano and processed cheese were found to be free from all tested pathogens but Kareish and Feta cheese were found to harbor $E$. coli and $Y$. entertocolitica. The results indicated the presence of some food borne pathogens in our food supply. Certain types of locally produced cheese still pose a significant health threat for the consumers. The finding of this study warrant the need for educational programs for dairy producers about the risks associated with consumption of certain cheeses manufactured from raw or insufficiently heated milk.
\end{abstract}

Dairy products have been recognized as being susceptible to post processing contamination. The predominant contaminants of processed dairy products have their origins from the raw milk supply. If one examines a list of bacterial pathogens commonly associated with raw milk, E.coli, Salmonella typhimurium, Listeria monocytogenes, Campylobacter jejuni, and Yersinia enterocolitica are just a few of many contaminants (Donnelly, 1990).

The ability of E.coli to survive in fermented dairy products made from raw milk (McIngvale et al., 2000 and Maher et al., 2001) is of major concern because the consumption of such products have led to human infection (Morgan et al., 1993 and Durch et al., 2000)

The first description of food borne listeriosis in human was associated with consumption of raw milk (Beckers et al., 1987) and listeriosis outbreaks from milk and cheeses have generated an interest in defining the survival of Listeria monocytogens in cheeses (Abdallah et al., 1993). Yersinia enterocolitica is related to Yersinia pestis, the organism responsible for bubonic plague. However, its virulence potential is not as great as that of $Y$. pestis. Food borne yersiniosis causes acute to severe gastrointestinal discomfort with pseudoappendecitis that is frequently observed in young children.

This study was designed to explore the microbiological characteristics of some locally produced cheeses that sold in Beni-Suef city.

\section{Material and methods}

Thirty samples of Kareish, processed, Feta and Romano cheese were collected randomly from different area in Beni-Suef governorate. Samples under cooling condition were sent to the lab for bacteriological examination. $25 \mathrm{gm}$ of each sample was weighted and added to $225 \mathrm{ml}$ of sterile peptone water in a stomached bag. The sample was homogenized in a lab-Tek 400 stomacher (Tekmar, Cincinnati, OH). Further serial dilution of the initial homogenate were prepared in dilution fluid and $0.1 \mathrm{ml}$ volumes of appropriate dilutions spread in duplicate onto selected media for enumeration of pathogen to determine the total microbial load. Aerobic plate counts were made on plate count agar (Difco, Detroit, Michigan).

E. coli O157: IMS was performed on one $\mathrm{ml}$ of enriched cultures and $20 \mu \mathrm{l}$ of magnetic beads coated with an antibodies prepared to the lipopolysaccharided of E. coli O157 (Dynabeads anti-E. coli $\mathrm{O}$ 157, Dynal INC., lake success, NY) were transferred in a $1.5 \mathrm{ml}$ micro centrifuge tube. The beads were suspended, mixed, incubated at room temperature and rotated at $30 \mathrm{rpm}$ for $30 \mathrm{~min}$ on an Orbitron Rotator II (Fisher Scientific, Mississauga, ON). Samples were placed in a magnetic particle concentrator (MPC 10, Dynal) for three minutes and washed twice in lambda buffer $(2.5 \mathrm{gm} \mathrm{Mg}$ $\mathrm{SO}_{4} .7 \mathrm{H}_{2} \mathrm{O}, 0.006$ g gelatin, $6 \mathrm{ml} 0.1 \mathrm{M}$ tris buffer, pH. 7.2, in 11 distilled water) (Chapman et al., 2001) After the final wash a final volume 
of $100 \mu \mathrm{l}$ was obtained. After IMS the final sample was plated on Sorbitol MacConkey agar. Plates were incubated for $24 \mathrm{~h}$ at $37^{\circ} \mathrm{C}$.

Listeria monocytogens was isolated after enrichment on listeria enrichment broth (Difco) on modified Oxford agar (Oxoid, Unipath Ltd, Basingstoke, England) according to (McClain and Lee 1989). MOX plates were incubated at $35^{\circ} \mathrm{C}$ for $24 \mathrm{~h}$ after which 5 presumptive colonies were streaked onto $\mathrm{BHI}$ for purification and incubated at $35^{\circ} \mathrm{C}$ for $24 \mathrm{~h}$. Presumptive Listeria isolates were confirmed and identified based on the results of Gram stain, catalase reaction, typical umbrella motility, and fermentation of mannitol, rahmnose and xylose. A modified CAMP test for enhanced haemolysis in the presence of Staphylococcus aureus alone was performed (McKellar, 1994). The species of all isolates were confirmed by use of APIListeria (BioMerieux) identification kit.

Salmonella was isolated by using standard procedure from Dynal Manual using antiSalmonella antibodies. After IMS, the final samples were plated onto xylose lysine desoxycholate agar (Merck). Plates were incubated at $35^{\circ} \mathrm{C}$ for $24 \mathrm{~h}$. Colonies presumptive for Salmonella were inoculated onto triple sugar agar (Difco) and urease agar (Difco). Organism was then identified by API-20E identification kit (Biomerieux) ( Andrews et al., 1992).

$Y$. enterocolitica was isolated on Yersinia selective agar base (Difco, Detroit, Michigan) containing the CIN (ceftsulodin-irgasannovobiocin) supplement (Difco) after $48 \mathrm{~h}$ incubations at $25^{\circ} \mathrm{C}$. Colonies with characteristics of Yersinia were examined with API-20E

\section{Results and discussion}

Table (1): Surveillance of food borne pathogens in selected cheeses.

\begin{tabular}{ccccccc}
\hline $\begin{array}{c}\text { Type of } \\
\text { samples }\end{array}$ & $\begin{array}{c}\text { No. of } \\
\text { sample } \\
\text { examined }\end{array}$ & $\begin{array}{c}\text { APC* } \\
(\text { Mean } \\
\left.\log _{10}\right)\end{array}$ & $\begin{array}{c}\text { E. coli } \\
\text { O157: H7 }\end{array}$ & $\begin{array}{c}\text { Listeria } \\
\text { Spp. }\end{array}$ & $\begin{array}{c}\text { Salmonella } \\
\text { Spp. }\end{array}$ & $\begin{array}{c}\boldsymbol{Y} \text {. } \\
\text { enterocolitica }\end{array}$ \\
\hline $\begin{array}{c}\text { Kariesh } \\
\text { cheese }\end{array}$ & 30 & 9.97 & $2(6.7 \%)$ & $5(16.7 \%)$ & 0 & $1(3.3 \%)$ \\
$\begin{array}{c}\text { Processed } \\
\text { cheese }\end{array}$ & 30 & 8.6 & 0 & 0 & 0 & 0 \\
$\begin{array}{c}\text { Feta cheese } \\
\begin{array}{c}\text { Romano } \\
\text { cheese }\end{array}\end{array}$ & 30 & 7.9 & 0 & $2(6.7 \%)$ & 0 & $3(10 \%)$ \\
\hline
\end{tabular}

identification kit (BioMerieux) (Weagant et al., 1992). The results in Table 1revealed that high aerobic plate count was obtained for all types of examined cheeses. Highest number obtained for Kariesh cheese as the mean of $\log _{10}(9.97$ $\mathrm{CFU} / \mathrm{gm})$ and the lowest for Romano cheese mean $\log _{10}(7.1 \mathrm{CFU} / \mathrm{gm})$. This may be due to the unhygienic condition under which Kariesh cheese was handled and the insufficient heat treatment. Kariesh cheese was also found to harbor E. coli $\mathrm{O} 157: \mathrm{H7}$, Listeria spp. and $Y$. enterocolitica where $2(6.7 \%), 5(16.7 \%), 1$ $(3.3 \%)$ were detected respectively. Feta cheese was found to contain $2(6.7 \%)$ Listeria spp. and $3(10 \%)$ Y. enterocolitica.

Processed cheese and Romano cheese were found to be negative for all the tested pathogens. The ability of $E$. coli to grow and survive during manufacture in fresh (Arocha et al., 1992), hard (Reitsma and Henning, 1996) and Camembert
(Ramsaran et al., 1998) cheeses investigated, in fresh cheese, E. coli has grown from an initial level of about $10^{5} \mathrm{cfu} / \mathrm{ml}$ to final number about $10^{7} \mathrm{cfu} / \mathrm{g}$ during the manufacture. However, during the heating phase, total inactivation occurred. L. monocytogenes was not detected in any of the examined samples. The only detected Listeria spp. in Kariesh cheese was Listeria innocua and the result was higher than those obtained by (Fathi and Nagah, 1992). Listeria innocua is the species that frequently isolated from raw milk, (Lovett et al., 1985; Farber et al., 1988 and El-Leboudy and Fayed 1992). Abd ElGawad (1998) reported the presence of Listeria monocytogenes in $1 \%$ of examined raw milk samples but could not isolate the pathogenic strain in any kind of the tested cheeses. The possibility that the growth of $L$. monocytogenes was suppressed by the associated microflora (McLauchin et al., 1990), pointed out that the 
detection of Listeria other than $L$. monocytogenes likely to indicate an increased risk of contamination by L. monocytogenes, because the physiology and habitat of different species are very similar.

Yersinia incidence in our samples is lower than that is reported before (Hamama et al., 1992) they tested a total of 227 samples of milk and dairy products, Yersinia species were recovered from 11 out of 30 raw milk samples $(36.6 \%)$, one out of 20 pasteurized milk samples (5\%), 15 out of 63 traditional fermented milk samples (23.8\%), 7 out of 94 cheeses and 1 out of 20 cream samples (5\%). Jayarao and Henning (2001) examined the prevalence of food borne pathogen in milk and found that Campylobacter jejuni, shiga-toxin producing $E$. coli, $L$. monocytogenes, Salmonella spp. and $Y$. enterocolitica were detected in 9.2, 3.8, 4.6, 6.1, and $6.1 \%$ of examined milk samples respectively.

The mechanism of raw milk contamination is unclear but in vitro studies have suggested that teat contamination could lead to intra-mammary infection. Faecal contamination, rumen contents, saliva and the farm environment are other routes of transmission. Contamination of the milk will result in contamination of the equipment used for milking, filtering, cooling, farm personnel and storage as well as subsequently produced dairy products.

Prevention and control of food borne disease constitute a problem of worldwide concern. Identification of sources of microbial contamination in raw products, processing environment and ingredients, the entrance of pathogens to processed food products leads to better control. These measures in combination with strict sanitation programs and improved testing procedure will ultimately enable the control of the incidence of food borne diseases.

\section{References}

Abdallah, O. M.; Christen, G. L. and Davidson, P. M. (1993): Chemical composition of and Listeria monocytogenes survival in white pickled cheese. J. Food Prot., 56: 841-846.

Abd EL-Gawad, M. H (1998): Studies on Listeria monocytogenes in milk and some dairy products. $\mathrm{Ph}$. D. Thesis. Cairo Univ., Beni-Suef Br., Fac. Vet. Med.,Egypt.

Andrews W. K.; Bruce, V. R.; June, G.; Satchell, F. and Sherrod, P. (1992): Salmonella. In FDA Bacteriological Analytical Manuals. $7^{\text {th }}$ ed. Assoc.Off. Analytical Chemist, Arlington, VA., pp., 51-70.

Arocha, M. M.; Mc Vey, M.; Loder, S. D.; Rupnow, J. H. and Bullerman, L. (1992): Behaviour of enteroheamorrhagic E.coli $\mathrm{O} 157: \mathrm{H} 7$ during manufacture of cottage cheese. Food Prot., 55: 379-381.
Beckers, H.; Soentoro, P. and Delfgou-Van, E. H. (1987): The occurrence of listeria monocytogenes in soft cheeses and raw milk and its resistance to heat. Int. J. Food Microbiol., 4: 249-256.

Chapman, P. A.; Ellin, M.; Ashton R. and Shafique, W. (2001): Comparison of culture, PCR and immunoassays for detecting Escherichia coli O157 following enrichment culture and immunomagnetic separation performed on naturally contaminated raw meat products. Int. J. Food Microbiol., 68: 11-20.

Donnelly, W.C. (1990): Concerns of microbial pathogens in association with dairy foods. J. Dairy Sci., 73: 16561661.

Durch, J.; Ringhand, T.; Manner, K.; Proetor, M.; Davis, J. and Boxrud, D. (2000): Outbreak of Escherichia coli O157: H 7 infection associated with eating fresh cheese crudes. Morbidity and Mortality Weekly Report, 49: 911913.

El-Leboudy, A. A. and Fayed, M. A. (1992): Incidence of Listeria in raw milk. Assiut Vet. Med. J., 27: 134-139.

Farber, J. M.; Sanders, G. W.; and Malcolm, A. S. (1988): The presence of Listeria spp. in raw milk in Ontario. Can. J. Microbiol., 34: 95-100.

Fathi, S. M. and Nagah, S. (1992): A survey of some selected food items for the presence of Listeria monocytogenes and other Listeria species. Assiut Vet. Med. J., 27: 115-119.

Hamama, A.; El Marrakachi, A. and El-Othmani, F. (1992): Occurrence of Yersinia enterocolitica in milk and dairy products in Morocco. Int. J. Food Microbiol., 16:6977.

Jayarao, B. M. and Henning, D. R. (2001): Prevalence of food-borne pathogens in bulk tank milk. J. Dairy Sci., 84: 2157-2162.

Lovette, J.; Frances, D. W.; Hunt, J. M. and Grawford, R. G. (1985): A survey for the incidence of Listeria monocytogenes in raw milk. Dairy and food Sanitation. 10: 399-400.

Maher M. M.; Jordan, K. N.; Upton, M. E. and Coffey, A. (2001): Growth and survival of E. coli O157:H7 during the manufacture and ripening of a smear-ripened cheese produced from raw milk. J. Appl. Microbiol., 90: 201-207.

McClain, D. and Lee, W. H. (1989): FSIS method for isolation and identification of Listeria monocytogenes from processed meat and poultry products. Division Lab. Comm. no. 57. U.S. Dept. Agri. Food Safety Inspc. Serv., Washington, D.C.

McKellar, R, C. (1994): Use of the CAMP test for identification of Listeria monocytogenes. Appl. Env. Microbiol., 60: 4219-4225.

McLauchlin, J.; Greenwood, M. H. and Pini, P. N. (1990): The Occurrence of Listeria monocytogenes in cheese from a manufacture associated with a case of lisreiosis . Int. J. Food Microbiol., 10:255-262.

McIngvale, S. C.; Chen, X. Q.; McKillip, J. L. and Dreake, M. A. (2000): Survival of Escherichia coli O157:H7 in buttermilk as affected by contamination point and storage temperature. J. Food Prot., 63: 441-444.

Morgan, D.; Newman. C. P.; Hutchinson, D. N.; Walker, A. M.; Rowe, B. and Majid, F. (1993): Vero toxin producing Escherichia coli O157:H7 infection associated with the consumption of yogurt. Epidem. Infect. 111: 181-187.

Ramsaran, H.; Chen, J.; Brunke, B.; Hill, A. and Griffiths, M. W. (1998): Survival bioluminescent Listeria monocytogenes and E. coli O157:H7 in soft cheese. J. Dairy Sci., 81: 1810-1817. 
Reitsma, C. J. and Henning, D. R. (1996): Survival of Enteroheamorrhagic E. coli O157:H7 during manufacture and curing of cheddar cheese. Food Prot. 59: 460-464.
Weagent. S. D.; Fengo, P. and Stanfield, J. T. (1992): Yersinia entertocolitica and Yersinia pseudotuberculosis. FDA Bacteriological Analytical Manual. $7^{\text {th }}$ ed. Association of Official Analytical Chemists. Arlington.VA. pp., 95-109. 